\title{
Subterranean Clover on Southern Pine Range: Potential Benefits to Game
}

\author{
KENNETH F. RIBBECK, MARK K. JOHNSON, AND KEN DANCAK
}

\begin{abstract}
Wildlife habitat is an important component of forested lands in the South. We examined effects of silvicultural practices and understory management on abundance of arthropods for wild turkey (Meleagris gallopavo) and bobwhite (Colinus virginianus). Plots $(\simeq 0.1 \mathrm{ha})$ of southern pine timber $(25-35$ years old $)$ were thinned or cleared and were planted with subterranean clover (Trifolium subterraneum) or were allowed to produce native vegetation. Arthropods were most abundant in clearings for both understory treatments: $127 \pm 15$ (subterranean clover), $45 \pm 5$ (native) per plot. Abundance of arthropods on pine forested plots with a subterranean clover understory was often greater than abundance of arthropods on cleared plots with native vegetation. Many of the arthropods sampled were the kinds often used by wild turkey and bobwhite. Subterranean clover production on forested plots was about $70 \%$ of production on cleared plots. Arthropods from 5 of 8 orders were significantly $(P<0.05)$ more abundant in subterranean clover plots compared to native vegetation. Abundance of arthropods was significantly $(P<0.05)$ associated with forage yield. Dead subterranean clover provided more arthropods in summer than live native vegetation. Planting subterranean clover in Southern pine timber offers a good alternative to removal of timber production for improving wildlife habitat and for integrating livestock and game management practices. Costs for establishing $(\approx \$ 100 / \mathrm{ha})$ and maintaining $(\approx 550 / \mathrm{ha} / \mathrm{yr})$ subterranean clover under pine timber are less than the potential loss in timber revenue (\$125 to 340/ha/yr) associated with maintaining clearings.
\end{abstract}

Key Words: Trifolium subterraneum, arthropods, bobwhite, deer, quail, wild turkey

Managed pine forests in the South supply enough cover for successful nesting, but bobwhite carrying capacities are frequently low because arthropods are often scarce (Hurst 1972). Clearcuts in forests are recommended to establish sites where arthropods are abundant and readily available to bobwhite and wild turkey (Stoddard 1931, Wheeler 1948, McGinnes and Ripley 1962, Lewis 1964). Cleared areas tend to support higher arthropods populations than areas under timber canopies (Speake et al. 1975) because understory forage production increases as timber density decreases (Wolters 1981). Planting clearings with cool-season forage crops is a common practice used to attract deer for harvest and for supplemental feed. However, establishment of clearings may require unscheduled clearcutting resulting in a loss of timber revenue.

The purpose of this study was to determine whether planting subterranean clover in forested plots is a viable alternative to clearcutting for creating game food plots. The approach used in our study was to compare subterranean clover forage production and arthropod abundance for the types useful to bobwhite and wild turkey among clearings, pine forests, and pine forests and clearings planted with subterranean clover.

\section{Study Area}

The study was performed at Louisiana State University Agricul-

\footnotetext{
Authors are graduate research assistants and (Johnson) associate professor, School of Forestry, Wildlife, and Fisheries, Louisiana State University Agricultural Center, Louisiana Agricultural Experiment Station, Baton Rouge 70803.

For help with field work, we thank L.G. Davis, J.H. Render, and S.S. Quisenberry This paper represents a contribution to Louisiana Agricultural Experiment Station, Project LA 2154.

Manuscript accepted 8 September 1986
}

tural Center's Idlewild Research Station, located approximately 5 km south of Clinton, Louisiana, in East Feliciana Parish. Fortyeight $(\simeq 0.1-$ ha) plots established by Davis $(1983)$ were used for this study. Understory composition consisted primarily of blackberry and dewberry (Rubus spp.), sedges (Carex spp.), rushes (Juncus spp.), beak rush (Rhynchospora sp.), dog-fennel (Eupatorium capillifolium), thistle (Carduus sp.), panic grasses (Panicum spp.), carpet grass (Axonopus affinis), bluestems (Andropogon spp.), bahia grass (Paspalum notatum), poor-joe (Diodia teres), French mulberry (Callicarpa americana), and sweetleaf (Symplocos tinctoria).

Soils are of the Providence silt loam series. Soil samples were collected in May 1983 from each study plot. Samples were analyzed according to standard A.O.A.C. (1970) techniques at the Soil Testing Laboratory, LSU, Baton Rouge. Soil pH ranged from 4.2 to 5.2. Average organic matter content was $3.6 \%$. Mean available phosphorus and potassium were $5 \mathrm{ppm}$ and $58 \mathrm{ppm}$, respectively. Precipitation was monitored on the research station during the study period (25 February through 27 October 1983); $52.58 \mathrm{~cm}$ (20.7 in).

\section{Methods}

The study consisted of 2 treatments: a native vegetation understory and an understory seeded with subterranean clover during fall 1981 and fertilized with $224 \mathrm{~kg} /$ ha of $0-24-24\left(\mathrm{~N}, \mathrm{P}_{2} \mathrm{O}_{5}, \mathrm{~K}_{2} \mathrm{O}\right)$ during fall 1981 and 1982 . For each of the 2 treatments, there were 3 plots each that were cleared or thinned to goals of about 9,18 , or $27 \mathrm{~m}^{2} /$ ha of pine basal area (25 to 35-year-old loblolly (Pinus taeda) and shortleaf ( $P$. echinata) pine) for a total of 12 plots per treatment. All hardwoods were removed. The resulting study area consisted of 6 clearings and 18 forested plots. Specific methods of plot establishment and annual management are reported elsewhere (Johnson et al. 1986).

\section{Arthropod Sampling}

We collected arthropod samples every 2 weeks from midFebruary through mid-October 1983 . However, native understoryvegetation became too dense for proper arthropod sampling by late August. Plots were mowed and burned in late August and sampled again in October, 1983. This sampling period (February through October) covered the peak brooding periods of wild turkey (Mosbey and Handley 1943, Bailey and Rinel 1967) and bobwhite (Simpson 1972, Stanford 1972), and peak production of subterranean clover (Davis 1983).

Sampling was done after 10:00 a.m. on clear days to minimize sampling errors due to variations in moisture on vegetation. A D-Vac (D-Vac, Ltd., Post Office Box 2095, Riverside, Calif.) suction sampler, equipped with a $0.09-\mathrm{m}^{2}$ collecting head, was used for sampling arthropod populations. Martin and McGinnes (1975) found the D-Vac method of sampling provided an efficient means of collecting those insects available to turkey poults. We assumed that the number of arthropods collected by the D-Vac provided estimates of relative arthropod availability to bobwhite and wild turkey.

On the day prior to sampling, transects ( 1 transect per plot; $6 \mathrm{~m}$ by $0.34 \mathrm{~m}=2.04 \mathrm{~m}^{2}$ ) were randomly established on each treatment. Samples were taken at a pace of $0.3 \mathrm{~m} / \mathrm{second}$, similar to the method described by Whitemore et al. (1981). Upon reaching the end of the sampling transect, the nylon collection bag was removed 
from the D-Vac, tied with a rubber band, and placed into a kill jar charged with ethyl acetate.

After removing the nylon bags from the kill jars, we placed the contents into petri dishes. Arthropods in each sample were sorted by taxonomic Order and counted.

\section{Vegetative Sampling}

During each sampling period, 3 vegetation samples were collected from each $0.09-\mathrm{m}^{2}$ frame on transect. Samples were oven dried at $80^{\circ} \mathrm{C}$ for $48 \mathrm{~h}$ and weighed to the nearest $0.1 \mathrm{~g}$. Data for the 3 samples were averaged to obtain an estimate of forage production for each transect. Native vegetation was clipped during its growing season, late-March through August (10 sampling dates). Subterranean clover, a cool-season annual, was clipped only during its growing season, February through early May (7 sampling dates).

\section{Overstory Relationships}

Densiometer measurements were taken over each clipped vegetation plot according to the 17-point technique described by Stricker (1959). Densiometer measurements were averaged to obtain an estimate of percent canopy cover over each transect. These data were used to describe relationships between timber density, forage production, and arthropod abundance. For practical comparisons, pine basal areas associated with each transect were also recorded. Data were classified according to the original thinning goal that the plot was most similar to. This resulted in unequal sample sizes for comparisons of data among thinning goals because actual pine basal areas varied significantly from the original thinning performed in 1981.

\section{Statistical Analysis}

Tests using the normal distribution were used to compare mean arthropod abundance between the treatments because means for each transect were averaged among plots so that comparisons were made using means of means. For each treatment, linear model procedures were used for analysis of variance to determine whether forage production, canopy cover, or sampling period significantly affected arthropod availability (Steel and Torrie 1980). Pine thinning goal was not used as a block treatment for analysis because Davis (1983) found that relationships between pine density and understory production were more strongly associated with canopy cover than with pine basal area.

\section{Results}

\section{Effects of Treatments}

Arthropod availability was not significantly affected by sampling period when variation due to forage production was accounted for $(P>0.05)$. Therefore, our data were combined among sampling periods for further analyses. Arthropod abundance was greater on subterranean clover plots than those with native vegetation all months except October ( $P<0.05$ ) (Table 1).

Arthropod abundance varied between treatments for 5 of 8 Orders (Table 2). Subterranean clover supported more Coleopterans, Homopterans, Orthopterans, Hymenopterans, and Dipterans than native vegetation $(P<0.05)$. There were no significant differences in abundance of Hemipterans, Lepidopterans, and Arachnids between the 2 treatments $(P>0.05)$. Live subterranean clover generally supported more arthropods than live native vegetation for similar levels of production (Table 3), and dead subterranean clover (June-October) provided more arthropods than live native vegetation. Arthropod abundance was significantly associated with subterranean clover yield $(P<0.05)$.

\section{Effects of Forest Canopy}

We found that arthropods were significantly more abundant in clearings for both treatments than under forest canopy. Therefore, the availability of arthropods for wild turkey and bobwhite would probably be enhanced by managing timber for saw logs and poles because this type of management results in stands with the least
Table 1. Mean ( \pm SE) arthropod abundance (number $/ 2.04 \mathrm{~m}^{2}$ ) compared between native vegetation and subterranean clover under mature southern pine forest from February through Oetober 1983. Data are means of means from 12 plots which were generally sampled every 2 weeks. For every month arthropods were significantly more abundant on subterranean clover plots $(P<0.05)$.

\begin{tabular}{llcr}
\hline & & \multicolumn{2}{c}{ Number } \\
\cline { 2 - 4 } Month & N & Subterranean Clover & Native \\
\hline February & 12 & $58 \pm 19$ & $5 \pm 2$ \\
March & 36 & $77 \pm 11$ & $18 \pm 3$ \\
April & 24 & $135 \pm 27$ & $27 \pm 3$ \\
May & 24 & $116 \pm 15$ & $43 \pm 6$ \\
June & 24 & $87 \pm 9$ & $49 \pm 4$ \\
July & 24 & $61 \pm 5$ & $38 \pm 3$ \\
August & 12 & $60 \pm 5$ & $29 \pm 4$ \\
October & 12 & $44 \pm 21$ & $28 \pm 10$ \\
\hline
\end{tabular}

Table 2. Mean ( $\pm \mathrm{SE}$ ) arthropod abundance (number $/ 2.04 \mathrm{~m}^{2}$ ) for 8 taxonomic Orders compared between native vegetation and subterranean clover treatments in a mature southern pine forest. Data averaged were means of 12 plots for 14 sampling periods so that $\mathrm{N}=168$ for each order. Means (in the same row) followed by the same letter are not significantly different at the $(P<0.05)$.

\begin{tabular}{lcc}
\hline \hline & \multicolumn{2}{c}{ Treatments } \\
\cline { 2 - 3 } Order & Subterranean Clover & Native \\
\hline Diptera & $48.3 \pm 4.9 \mathrm{~A}$ & $9.1 \pm 0.8 \mathrm{~B}$ \\
Homoptera & $9.9 \pm 0.8 \mathrm{~A}$ & $5.2 \pm 0.7 \mathrm{~B}$ \\
Orthroptera & $7.7 \pm 1.0 \mathrm{~A}$ & $3.9 \pm 0.4 \mathrm{~B}$ \\
Hymenoptera & $6.0 \pm 0.7 \mathrm{~A}$ & $3.1 \pm 0.1 \mathrm{~B}$ \\
Coleoptera & $5.0 \pm 0.9 \mathrm{~A}$ & $0.9 \pm 0.1 \mathrm{~B}$ \\
Arachnida & $4.3 \pm 0.3 \mathrm{~A}$ & $4.4 \pm 0.3 \mathrm{~A}$ \\
Hemiptera & $3.3 \pm 0.4 \mathrm{~A}$ & $3.6 \pm 0.4 \mathrm{~A}$ \\
Lepidoptera & $0.3 \pm 0.1 \mathrm{~A}$ & $0.1 \pm 0.1 \mathrm{~A}$ \\
\hline
\end{tabular}

Table 3. Mean ( $\pm \mathrm{SE}$ ) arthropod abundance per $12.04 \mathrm{~m}^{2}$ plot in clearings and under a mature southern pine forest for native vegetation and subterranean clover. Means followed by the same letter are not significantly different $(P<0.05)$.

\begin{tabular}{ccccc}
\hline \hline \multirow{2}{*}{$\begin{array}{c}\text { Pine Basal Area } \\
\left(\mathrm{m}^{2} / \mathrm{ha}\right)\end{array}$} & $\mathrm{N}$ & Subterranean clover & $\mathrm{N}$ & Native \\
\cline { 2 - 5 } & 48 & $127 \pm 15 \mathrm{~A}$ & 48 & $45 \pm 5 \mathrm{C}$ \\
0 & 53 & $63 \pm 5 \mathrm{~B}$ & 38 & $28 \pm 2 \mathrm{D}$ \\
9 & 43 & $79 \pm 10 \mathrm{~B}$ & 44 & $30 \pm 3 \mathrm{D}$ \\
18 & 24 & $61 \pm 10 \mathrm{~B}$ & 38 & $27 \pm 3 \mathrm{D}$ \\
27 & &
\end{tabular}

canopy cover. Arthropod abundance was significantly greater $(P<0.05)$ in the subterranean clover regardless of pine basal area than in clearings with native vegetation (Table 3).

\section{Discussion}

Dalke et al. (1946) found that unburned forest land offered a larger variety and quantity of ground inhabiting insects and other invertebrates than burned-over areas. However, Hurst (1978) found that the proportion of poult diets made up by animal food was higher on burned plots than on unburned plots in loblollyshortleaf pine forest. He attributed this to a greater availability of arthropods due to the more open understory created by prescribed burning. We suggest that any method used to disturb vegetative cover will increase availability of arthropods after vegetation becomes so dense as to make arthropods difficult to obtain. Pres- 
cribed burning is probably the least expensive method when conditions allow its use.

Davis (1983) found that subterranean clover established well on recently disturbed sites when seed was broadcast when the ground was wet; but each fall it needed fertilization and mowing, heavy grazing, or burning to remove native vegetation produced during summer. Management practices needed for maintaining subterranean clover appear to provide the greatest availability of arthropods for bobwhite and wild turkey.

Pine timber grown for sawlogs may produce about $\$ 125 / \mathrm{ha} / \mathrm{yr}$ if management intensity is low while highly managed stands may produce as much as about $\$ 340$ considering current stumpage prices paid for pine timber (Hotvedt 1983). The cost for establishing subterranean clover is about $\$ 100 /$ ha for seed and fertilizer and for fertilizer in later years about $\$ 50 /$ ha. Associated labor is less than that needed for maintaining clearings; suppression of native vegetation by subterranean clover reduces or eliminates the need for summer mowings. Although these figures vary among years due to market conditions, it is obvious that opportunity costs associated with removal of pine timber production are larger, and may be substantially larger, than costs for underplanting and managing subterranean clover in pine stands. Further, pine timber stocking levels that produced the greatest abundance of arthropods in this study are similar to basal area thinning goals normally recommended by silviculturalists. Therefore, use of subterranean clover under pine timber is compatible with normal pine timber management.

\section{Conclusions}

Gardner and Arner (1968) suggested that lack of animal proteins in the form of insects and other small invertebrates could be limiting wild turkey fecundity. Wild turkey poults and bobwhite chicks need high protein foods during early stages of life (Hamrick and Davis 1972, Hurst 1972, Tobler and Lewis 1980). This high protein demand, $\approx 28 \%$ for turkey poults (Marsden and Martin 1955), can be met only be eating large amounts of animal food, particularly insects (Hurst 1972, Eubanks and Dimmick 1974).

Delaney (1985) reported that about 1.5 ha of subterranean clover plots was sufficient to provide about $25 \%$ of the winter diets for 60-75 free-ranging deer (Odocoileus virginianus). He also determined that diet crude protein and total digestible nutrient were significantly improved compared to diets made up by native forage alone. In addition, average weights of yearling bucks improved after establishing subterranean clover plots for deer use. We believe that primary use of subterranean clover for deer would provide secondary benefits to other wildlife whether grown under pine timber or not.

During the course of these studies and those conducted by Delany (1985), bobwhite were observed on forested subterranean clover plots on numerous occasions, and wild turkeys were often observed on subterranean clover plots used for the deer studies. While Delany's studies provide strong evidence that subterranean clover plots can improve diet quality for deer, there is no proof that similar improvements were actually made for other game. However, we presume that improvements would probably occur where abundance of arthropods is a limiting factor due to infertility of native range.

On the basis of the results of this study and the findings of others regarding the importance of arthropods to bobwhite and wild turkey, we conclude that use of subterranean clover under managed pine timber for supplementing cattle in winter provides an economically reasonable method for integrating livestock and wildlife management.

\section{Literature Cited}

Associntion of Official Annlytical Chemists. 1970. Official methods of analysis. 11 th ed. Ass. Off. Anal. Chem. Washington, D.C.

Balley, R.W., and K.T. Rinell. 1967. Events in the turkey year. p. 73-92 In: O.H. Hewitt, ed. The wild turkey and its management. The Wildl. Soc. Washington D.C.

Dalke, P.D., A.S. Leopold, and D.L. Spencer. 1946. The ecology and management of the Wild Turkey in Missouri. Missouri Conserv. Comm. Tech. Bull. No. 1.

Devis, L.G. 1983. Production of subterranean clover in Louisiana pine forests. M.S. thesis, Louisiana State Univ., Baton Rouge.

Delany, B.W. 1985. Effects of cool-season food plots on white-tailed deer. M.S. thesis. Louisiana State Univ., Baton Rouge.

Eubanks, T.R., and R.W. Dimmick. 1974. Dietary patterns of bobwhite quail on Ames Plantation. Univ. Tenn. Agr. Exp. Sta. Bull. 534.

Gardner, D.T., and D.H. Amer. 1968. Food supplements and wild turkey reproduction. Trans. N. Amer. Wildl. and Nat. Res. Conf. 33:250-258.

Hamrick, W.J., and J.R. Davis. 1972. Summer food items of juvenile wild turkeys. Proc. Annu. Conf. Southeast Ass. Game Fish Comm. 28:85-89.

Hotvedt, J.E. 1983. Economic returns from one 29-year-old loblolly pine plantation. Louisiana Agr. 27:12-13.

Hurst, G.A. 1972. Insects and bobwhite quail brood habitat management. p. 65-82. In: J.A. Morrison and J.C. Lewis, eds. Proc. First Nat. Bobwhite Quail Symp. Oklahoma State Univ., Stillwater.

Johnson, M.K., L.G. Davia, K.F. Ribbeck, J.H. Render, and H.A. Pearson. 1986. Management of subterranean clover in pine forested range. J. Range Manage.. 39:454-457.

Lewis, J.C. 1964. Populations of wild turkey in relation to fields. Proc. Southeast. Ass. Game and Fish Comm. Conf. 18:49-56.

Marsden, S.J., and J.H. Martin. 1955. Turkey management. 6th Ed. Interstate Press, Danville, Ill.

Mertin, D.D., and B.S. McGinnes. 1975. Insect availability and use by turkeys in forest clearings. p. 70-75. In: L.K. Halls, ed. Proc. Third Nat. Wild Turkey Symp. Texas Chap. Wild. Soc., San Antonio.

MeGinnes, B.S., and T.H. Ripley. 1962. Evaluation of wild life response to forest wildlife management-a preliminary report. Proc. Soc. Amer. For.

Mosby, H.S., and C.O. Handley. 1943. The wild turkey in Virginia; its status, life history and management. Comm. of Game and Inland Fish., Richmond, Va.

Simpson, R.C. 1972. A study of bobwhite quail nest initiation dates, clutch sizes, and hatch sizes in southwest Georgia. p. 199-204. In: J.S. Morrison and J.C. Lewis, eds. Proc. First Nat. Bobwhite Quail Symp. Oklahoma State Univ. Stillwater.

Speake, D.W., T.E. Lynch, W.J. Fleming, G.A. Wright, and W.J. Hamrick. 1975. Habitat use and seasonal movements of wild turkeys in the Southeast. p. 122-130. In: J.K. Halls, ed. Proc. Third Nat. Wild Turkey Symp. Texas Chapter Wildl. Soc., San Antonio.

Steel, F.G.D., and J.H. Torrie. 1980. Principles and procedures of statistics. McGraw-Hill Book Co., New York.

Stoddard, H.L. 1931. The bobwhite quail: its habits, preservation and increase. C. Scribner's Sons, New York.

Strickler, G.S. 1959. Use of the densiometer to estimate density of forest canopy on permanent sample plots. USDA Forest Serv. Pac. Northwest Forest and Range Exp. Sta. Res. Note 180.

Tobler, S.L., and J.C. Lewis. 1980. Bobwhite foods in 6 Oklahoma habitats. Proc. Annu. Conf. Southeast. Ass. Fish and Wildl. Agencies 34:430-441.

Wheeler, R.J. 1948. The wild turkey in Alabama. Alabama Dept. Cons.

Whitemore, R.W., K.P. Pruess, and J.T. Nichols. 1981. Leafhopper and planthopper populations on 8 irrigated grasses grown for livestock forage. Environ. Entomol. 10:114-118.

Wolters, G.L. 1981. Timber thinning and prescribed burning as methods to increase herbage in grazed and protected longleaf pine range. J. Range Manage. 34:494-497. 